Energy Research Journal 1 (2): 182-188, 2010

ISSN 1949-0151

(C) 2010 Science Publications

\title{
Computational Study of Hybrid Water Heater with Evacuated Glass Tube Solar Collector and Rice Husk Combustion
}

\author{
Piyanun Charoensawan and Chaiwat Wannagosit \\ Department of Mechanical Engineering, Faculty of Engineering, \\ Naresuan University, Phitsanulok 65000, Thailand
}

\begin{abstract}
Problem statement: The thermal performance modeling of hybrid water heater with evacuated glass tube solar collector and flue gas of rice husk combustion was developed. The solar global radiation and ambient air temperature data used in the system modeling belongs Phitsanulok province from $7 \mathrm{am}-5 \mathrm{pm}$ in the summer season. Approach: The system can be divided into two parts, i.e., evacuated glass tube thermosyphon solar collector and thermosyphon heat exchanger with flue gas of rice husk combustion. The evacuated glass tube was a coaxial double-layer tube made of Borosilicate. Its outer tube diameter and inner tube diameter were 58 and $47 \mathrm{~mm}$ respectively. The inside cavity of evacuated glass tube holed thermosyphon which was made of copper tube and filled with R134a at the filling ratio of $70 \%$ of evaporator volume. For latter, the temperature and flow rate of flue gas that was released from the cyclone furnace and used as a heat source of heat exchanger were constant at $150^{\circ} \mathrm{C}$ and $50 \mathrm{~m}^{3} \mathrm{~min}^{-1}$. The heat exchanger was consisted of array of thermosyphon which was made of stainless steel tube and filled with distilled water at 50\% filling ratio of evaporator volume. Results: The effects of various parameters on the system performance were computational analyzed. The hybrid water heater system with optimum design of both thermal performance and economic can be obtained and produce the hot water at the temperature exceeding $70^{\circ} \mathrm{C}$ and the flow rate of $1 \mathrm{~m}^{3} \mathrm{day}^{-1}$. Conclusion: The thermal performance of this optimum hybrid water heater system was investigated along the time of the day in summer.
\end{abstract}

Key words: Hybrid water heater, evacuated tube thermosyphon collector, thermosyphon heat exchanger, rice husk combustion

\section{INTRODUCTION}

Since the fact that world's resources of fossil fuels are finite has been accepted worldwide, the renewable energy becomes important nowadays. Because Thailand is in tropical zone, the solar energy is interesting. One technology of solar energy utilizations is solar water heater. The solar energy is absorbed in thermal form and simultaneously transported into hot water by a solar collector. Although there are several types of solar collectors, one of them that is appropriate for the low temperature application and has the low heat loss is non focusing evacuated glass tube solar collector. Consequently many researches have concentrated on this collector (Balzar et al., 1996; Beikircher et al., 1996; Esen, 2004; Kim and Seo, 2007; Li and Wang, 2006; Morrison et al., 2004; Zhang and Yamaguchi, 2008). Both the single-phase open and the two-phase closed thermosyphons were applied in it. The thermal efficiency of single-phase open thermosyphon evacuated tube collector with using water as the heat transfer media was higher than that of various gases. However, two disadvantages was observed, viz., the evacuated glass tube was broken since the temperature variation of water suddenly happened in the glass tube and the non-circulation of water occurred at the bottom end of the evacuated tube. These problems difficultly occurred in another type of thermosyphon. The evacuated tube solar collector with two-phase closed thermosyphon was investigated in present research.

Although the solar water heater technology has been continually developed and can be easily implemented, there is the thermal performance limit since the solar radiation intensity is not uniform through a day and unavailable at night. Therefore in order to achieve the stable water heating system, the auxiliary heat source, i.e., electric heater, LPG, thermal storage unit was added into the system (Assilzadeh et al., 2005; Sharma et al., 2005). In Thailand, biomass is the alternative renewable energy.

Corresponding Author: Piyanun Charoensawan, Department of Mechanical Engineering, Faculty of Engineering, Naresuan University, Phitsanulok 65000, Thailand Tel: 05-596-4215 Fax: 05-596-4004 
Because the paddy farming is plenteously done through a year, the rice husk is interesting. Its heating value of combustion is relative high compared to the other residual agricultural products. The auxiliary heat is transferred from flue gas of rice husk combustion to water by a heat exchanger. Typically the cyclone furnace was used for the rice husk combustion at high efficiency of $50-80 \%$ with dependence on the rice husk consumption.

Therefore the hybrid water heater with evacuated glass tube solar collector and rice husk combustion was computational studied in this research and the twophase closed thermosyphons were also applied in this system.

\section{MATERIALS AND METHODS}

\section{Theoretical model:}

System description: The hybrid water heating system can be divided into two parts, i.e., evacuated glass tube thermosyphon solar collector and thermosyphon heat exchanger with flue gas of rice husk combustion as shown in Fig. 1. The details of each part are presented in Fig. 2 and 3. The structure of evacuated glass tube is a coaxial double-layer tube. The cross-sectional view is also presented to reveal thermosyphon existing in the evacuated tube. The condenser tank is well insulated. The water flow passes the condenser tank. For latter, the heat exchanger is consisted of array of thermosyphon. The water flow passes through the condenser section as the flue gas flow passes through the evaporator section.

The solar radiation is incident on the surface of evacuated tube collector. A high portion of the irradiation is transmitted through the outer tube wall of double-layer evacuated glass tube and then absorbed by the absorber surface of its inner tube wall which is coated with a special selective coating. Thereafter the thermal energy absorbed in this inner tube wall is transferred by thermosyphon from the evaporator that is inserted in the evacuated tube to the condenser that is held in the tank. The heat is removed from the condenser by the forced convective heat transfer of cold water pumped through the condenser tank. Then hot water at the outlet of condenser tank is passed in cross flow over the condenser section tubes of thermosyphon heat exchanger to receive the auxiliary thermal energy that is transferred from the rice husk combustion gas flowing across the evaporator section tubes of heat exchanger. The combustion of rice husk takes place in the cyclone furnace. The high temperature hot water at the outlet of heat exchanger is stored in the tank.

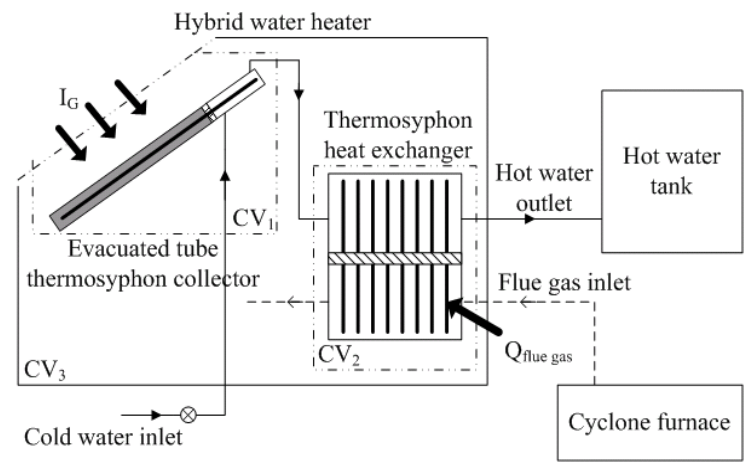

Fig. 1: Hybrid water heating system

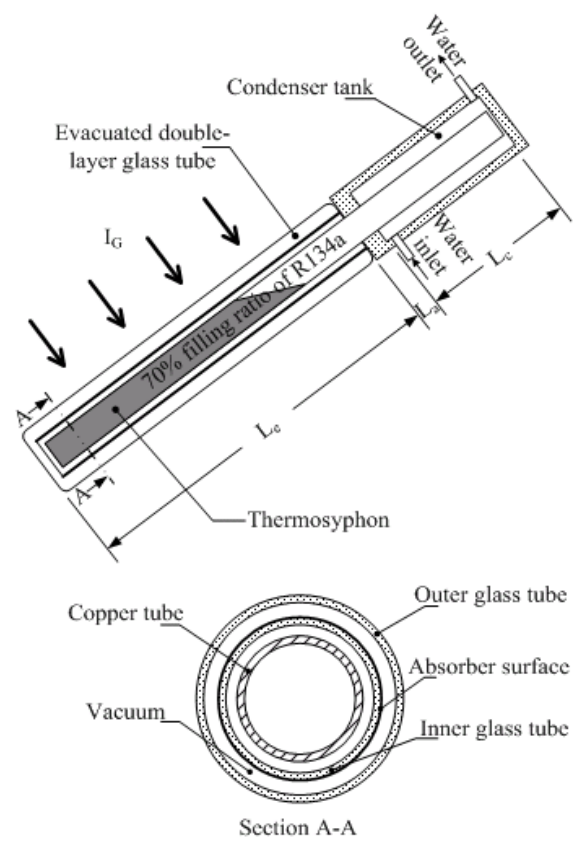

Fig. 2: Evacuated glass tube thermosyphon solar collector

Mathematical model and computer program: To model the system, it is necessary to suppose that:

- Uniform solar radiation is incident on the surface of evacuated glass tube in all directions around the tube

- Negligible heat loss from an adiabatic section of thermosyphon, frame structure of heat exchanger

- Negligible fouling resistance at the evaporator and condenser surfaces of heat exchanger

Applying the energy and mass balances on a control surface about the evacuated tube thermosyphon collector system $\left(\mathrm{CV}_{1}\right)$ as shown in Fig. 1 and 2, it follows that: 


$$
\begin{aligned}
& \mathrm{I}_{\mathrm{G}} \tau_{\mathrm{G}} \alpha_{\mathrm{A}} \mathrm{A}_{\mathrm{c}}-\mathrm{q}_{\text {loss }}+\dot{\mathrm{m}}_{\mathrm{w}} \mathrm{c}_{\mathrm{p}, \mathrm{w}}\left(\mathrm{T}_{\mathrm{w}, \mathrm{ic}}-\mathrm{T}_{\mathrm{w}, \mathrm{oc}}\right) \\
& =\mathrm{M}_{\mathrm{w}} \mathrm{c}_{\mathrm{p}, \mathrm{w}} \frac{\Delta \mathrm{T}_{\mathrm{w}}}{\Delta \mathrm{t}}
\end{aligned}
$$

Where:

$\mathrm{I}_{\mathrm{G}} \quad=$ The intensity of solar global radiation that is incident on the surface of all evacuated glass tubes of the collector

$\tau_{\mathrm{G}} \quad=$ The transmissivity of outer glass tube

$\alpha_{\mathrm{A}} \quad=$ The absorptivity of absorber surface

$\mathrm{A}_{\mathrm{c}} \quad=$ The surface area of the collector

$\mathrm{q}_{\mathrm{loss}} \quad=$ Heat loss from the collector

$\dot{\mathrm{m}}_{\mathrm{w}} \quad=$ The mass flow rate of water pumped through the condenser tank

$\mathrm{c}_{\mathrm{p}, \mathrm{w}} \quad=$ The water specific heat at constant pressure

$\mathrm{T}_{\mathrm{w}, \text { ic }}$ and $\mathrm{T}_{\mathrm{w}, \mathrm{oc}}=$ The water temperatures at inlet and outlet of tank respectively

$\mathrm{M}_{\mathrm{w}} \quad$ = The water mass within the tank

$\Delta \mathrm{T}_{\mathrm{w}} \quad=$ The temperature increment of water stored in the tank

$\Delta \mathrm{t} \quad=$ The storage time interval

The thermal efficiency of the collector system is evaluated as:

$$
\begin{aligned}
\eta_{\mathrm{c}} & =\mathrm{q}_{\mathrm{c}} / \mathrm{Q}_{\mathrm{G}} \\
& =\dot{\mathrm{m}}_{\mathrm{w}} \mathrm{c}_{\mathrm{p}, \mathrm{w}}\left(\mathrm{T}_{\mathrm{w}, \mathrm{oc}}-\mathrm{T}_{\mathrm{w}, \mathrm{ic}}\right) / \mathrm{I}_{\mathrm{G}} \mathrm{A}_{\mathrm{c}}
\end{aligned}
$$

Where:

$\mathrm{q}_{\mathrm{c}}=$ The heat gain of hot water from the solar collector

$\mathrm{Q}_{\mathrm{G}}=$ The total solar radiation rate incident on the collector surface area

Applying the heat transfer analysis of flow across bank of tubes and two-phase closed thermosyphon and the counterflow heat exchanger analysis with use of the log mean temperature difference on thermosyphon heat exchanger system as shown is Fig. 3, it follows that:

$\mathrm{q}_{\mathrm{HE}}=\mathrm{UA} \Delta \mathrm{T}_{\mathrm{lm}}$

Where:

$\mathrm{q}_{\mathrm{HE}}=$ Total heat transfer between the flue gas and water

$\mathrm{U}=$ The overall heat transfer coefficient of thermosyphon heat exchanger and

A $=$ The total heat transfer surface area of heat exchanger

$\Delta \mathrm{T}_{\mathrm{lm}}=$ The log mean temperature difference

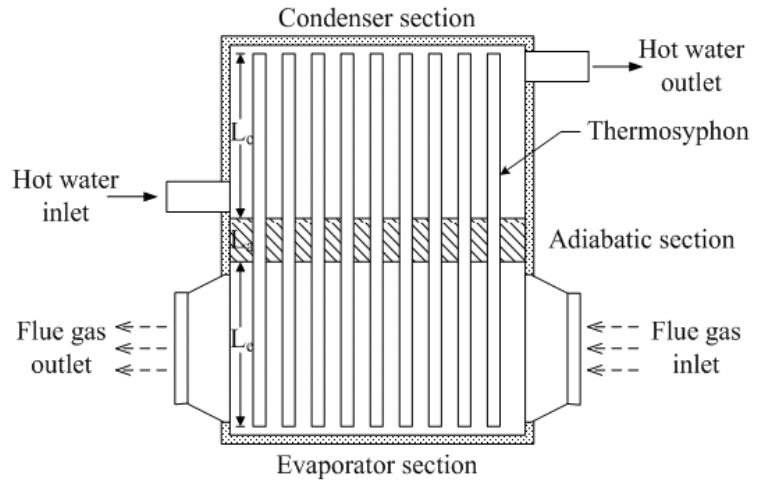

Fig. 3: Thermosyphon heat exchanger

$$
\Delta \mathrm{T}_{\mathrm{lm}}=\frac{\left(\mathrm{T}_{\mathrm{g}, \mathrm{o}}-\mathrm{T}_{\mathrm{w}, \mathrm{iHE}}\right)-\left(\mathrm{T}_{\mathrm{g}, \mathrm{i}}-\mathrm{T}_{\mathrm{w}, \mathrm{oHE}}\right)}{\ln \left(\frac{\mathrm{T}_{\mathrm{g}, \mathrm{o}}-\mathrm{T}_{\mathrm{w}, \mathrm{iHE}}}{\mathrm{T}_{\mathrm{g}, \mathrm{i}}-\mathrm{T}_{\mathrm{w}, \mathrm{oHE}}}\right)}
$$

Where:

$\mathrm{T}_{\mathrm{g}, \mathrm{i}}$ and $\mathrm{T}_{\mathrm{g}, \mathrm{o}} \quad=$ The flue gas temperatures at inlet and outlet of heat exchanger respectively

$\mathrm{T}_{\mathrm{w}, \mathrm{iHE}}$ and $\mathrm{T}_{\mathrm{w}, \mathrm{OHE}}=$ The water temperatures at inlet and outlet of heat exchanger respectively

In addition, it is supposed that $\mathrm{T}_{\mathrm{w}, \mathrm{iHE}}=\mathrm{T}_{\mathrm{w}, \mathrm{oc}}$. The conservation of energy is also applied on the control surface about the thermosyphon heat exchanger $\left(\mathrm{CV}_{2}\right)$ as shown in Fig. 1 and gives:

$\mathrm{q}_{\mathrm{HE}}=\dot{\mathrm{m}}_{\mathrm{g}} \mathrm{c}_{\mathrm{p}, \mathrm{g}}\left(\mathrm{T}_{\mathrm{g}, \mathrm{i}}-\mathrm{T}_{\mathrm{g}, \mathrm{o}}\right)$

and

$\mathrm{q}_{\mathrm{HE}}=\dot{\mathrm{m}}_{\mathrm{w}} \mathrm{c}_{\mathrm{p}, \mathrm{w}}\left(\mathrm{T}_{\mathrm{w}, \mathrm{OHE}}-\mathrm{T}_{\mathrm{w}, \mathrm{iHE}}\right)$

The heat exchanger effectiveness is also calculated as:

$\begin{aligned} \varepsilon & =\mathrm{q}_{\mathrm{HE}} / \mathrm{q}_{\max } \\ \mathrm{q}_{\max } & =\mathrm{C}_{\text {min }}\left(\mathrm{T}_{\mathrm{g}, \mathrm{i}}-\mathrm{T}_{\mathrm{w}, \mathrm{HE}}\right)\end{aligned}$

Where:

$\mathrm{q}_{\max }=$ The maximum possible heat transfer rate

$\mathrm{C}_{\min }=$ The minimum heat capacity rate

Consider the hybrid water heater system in Fig. 1 which is surrounded with the control surface $\mathrm{CV}_{1}$, the overall efficiency of system is defined as:

$\eta_{\mathrm{o}}=\frac{\mathrm{q}_{\mathrm{o}}}{\mathrm{Q}_{\mathrm{G}}+\mathrm{Q}_{\text {flue gas }}}=\frac{\dot{\mathrm{m}}_{\mathrm{w}} \mathrm{c}_{\mathrm{p}, \mathrm{w}}\left(\mathrm{T}_{\mathrm{w}, \mathrm{oHE}}-\mathrm{T}_{\mathrm{w}, \mathrm{c} c}\right)}{\mathrm{I}_{\mathrm{G}} \mathrm{A}_{\mathrm{c}}+\mathrm{Q}_{\text {flue gas }}}$ 
Where:

$\mathrm{q}_{\mathrm{o}} \quad=$ The heat gain of hot water from the hybrid water heater

$\mathrm{Q}_{\text {flue gas }}=$ The auxiliary heat of rice husk combustion that is released from the cyclone furnace

The equation is:

$\mathrm{Q}_{\text {flue gas }}=\eta_{\mathrm{f}}\left(\dot{\mathrm{m}}_{\text {rice husk }} \mathrm{LHV}\right)$

Where:

$\eta_{\mathrm{f}} \quad=$ The combustion efficiency of cyclone furnace

$\dot{\mathrm{m}}_{\text {rice husk }}=$ The rice husk consumption

LHV = The lower heating value of rice husk

The hybrid water heater system with optimum design of both thermal performance and economic was analyzed and it was necessary to specify the design conditions as follows:

- The system modeling was based on Thailand's climate data at Phitsanulok province

- The seasonal average values of solar radiation Intensity $\left(\mathrm{I}_{\mathrm{G}}\right)$ and ambient air Temperature $\left(\mathrm{T}_{\mathrm{a}}\right)$ in summer (February-May 2007) were used to analyze the system

- The evacuated glass tube is a coaxial double-layer tube made of Borosilicate with $58 \mathrm{~mm}$ outer tube diameter, $47 \mathrm{~mm}$ inner tube diameter and $1500 \mathrm{~mm}$ length

- Thermosyphon of collector was made of copper tube with $22.2 \mathrm{~mm}$ outside diameter and filled with $\mathrm{R} 134 \mathrm{a}$ at the filling ratio of $70 \%$ of evaporator volume. Its adiabatic length was $250 \mathrm{~mm}$

- Thermosyphon of heat exchanger was made of stainless steel tube (AISI 304 Type) with $27.2 \mathrm{~mm}$ outside diameter and filled with distilled water at $50 \%$ filling ratio

- Thermosyphon arrangement in heat exchanger was staggered with the longitudinal and transverse pitches were $60 \mathrm{~mm}$. The adiabatic length was $50 \mathrm{~mm}$

- The combustion of rice husk takes place in the cyclone furnace with rice husk consumption of $20 \mathrm{~kg} \mathrm{~h}^{-1}$ and the efficiency of $75 \%$. The flue gas temperature and flow rate were constant at $150^{\circ} \mathrm{C}$ and $50 \mathrm{~m}^{3} \min ^{-1}$

The variable parameters that affect on the system performance are number of evacuated glass tubes $\left(\mathrm{N}_{\mathrm{c}}\right)$, evaporator and condenser lengths of thermosyphon $\left(\mathrm{L}_{\mathrm{e}}\right.$ and $\mathrm{L}_{\mathrm{c}}$ ), number of tubes in transverse and longitudinal planes $\left(\mathrm{N}_{\mathrm{T}}\right.$ and $\left.\mathrm{N}_{\mathrm{L}}\right)$. The computational steps for modeling the system are described in Fig. 4.

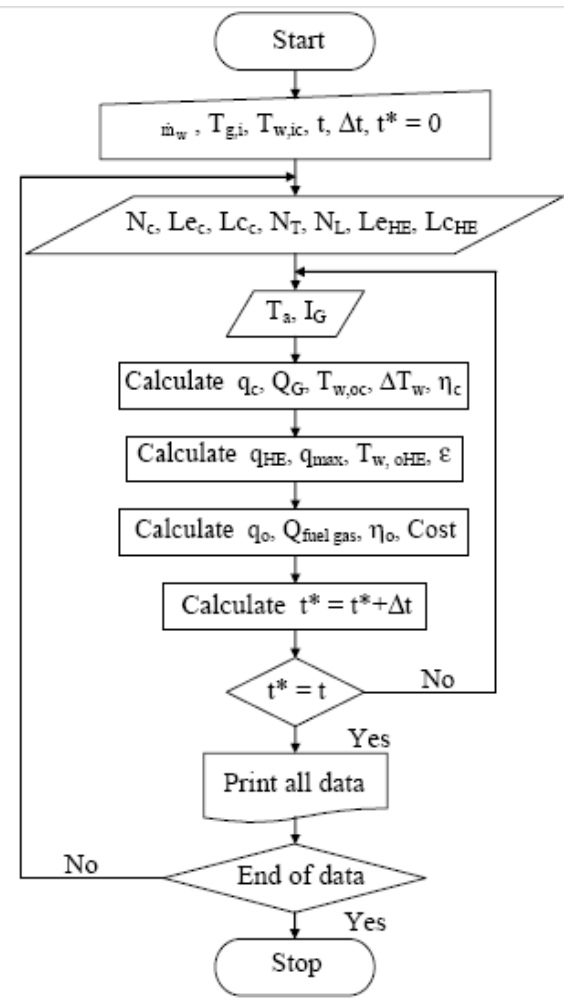

Fig. 4: Computational steps for system modeling

The hybrid system was analyzed along the standard local time of the day from 7 am-5:00 pm. Both thermal performance and economic of system were investigated by varying all parameters as mentioned above. The system optimization was obtained and the performance of optimum system was presented.

\section{RESULTS AND DISCUSSION}

Optimum system: In order to produce the hot water at the temperature exceeding $70^{\circ} \mathrm{C}$ and the volumetric flow rate of $1 \mathrm{~m}^{3} \mathrm{day}^{-1}$, the specification of hybrid water heater with relative high efficiency and low cost is shown in Table 1 . The thermal performance of this optimum hybrid water heater system was investigated along the day in summer.

Thermal performance of hybrid system: The seasonal average values of solar intensity and air temperature in summer as shown in Fig. 5 are applied to model the system along the standard local time of the day from 7:00 am-5:00 pm. The solar intensity and air temperature increase along the local time to the maximum values at noon thereafter they decrease. However the intensity and temperature in the afternoon tend to be higher than that in the morning. Because the solar intensity and the air temperature which influence on the system operation 
vary along the local time, the system performance also changes as presented in Fig. 6-8.

Figure 6 shows the temperature variation of water and flue gas along the local time of the day from 7:00 am$5: 00 \mathrm{pm}$. The water temperature at inlet of collector $\left(\mathrm{T}_{\mathrm{w}, \mathrm{ic}}\right)$ and the flue gas temperature at inlet of heat exchanger $\left(\mathrm{T}_{\mathrm{g}, \mathrm{i}}\right)$ are always maintained at 25 and $150^{\circ} \mathrm{C}$ respectively.

Table 1: Summary of hybrid water heater specification

Specifications

Dimensions

Collector

Number of evacuated glass tubes or thermosyphon

15

Outer tube diameter of glass tube

Inner tube diameter of glass tube

Evaporator or glass tube length

Adiabatic length

Condenser length

Outside diameter of copper tube

Inside diameter of copper tube

Working fluid

Heat exchanger

Number of tubes in transverse plane

Number of tubes in longitudinal plane

Number of thermosyphon

Longitudinal pitch

Transverse pitch

Evaporator length

Adiabatic length

Condenser length

Outside diameter of steel tube

Inside diameter of steel tube

Working fluid

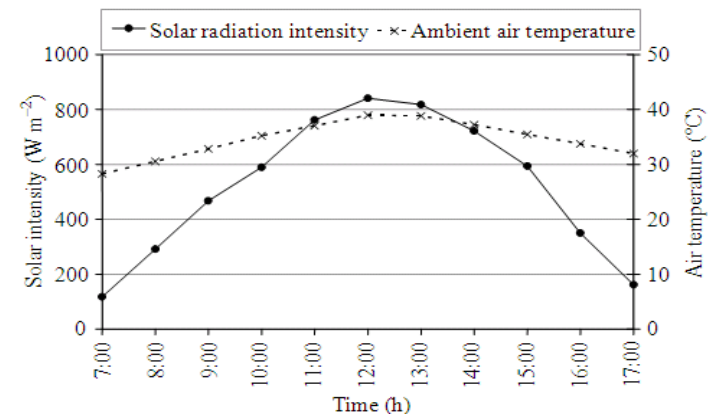

Fig. 5: Variation of solar intensity and air temperature along the local time in summer

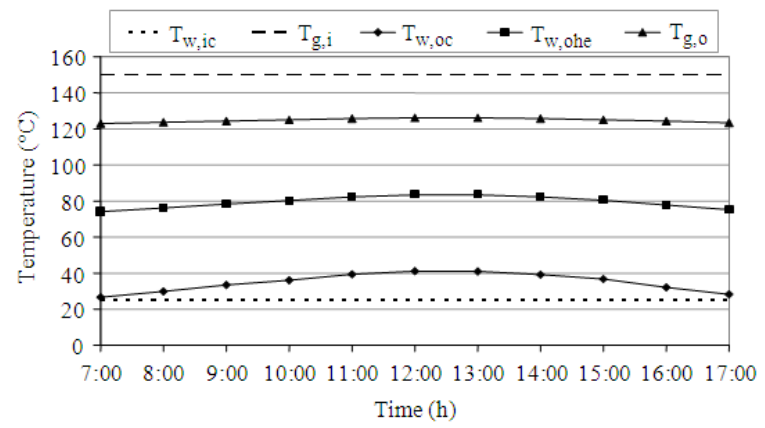

Fig. 6: Temperature variation of water and flue gas along the local time
In the morning, with increasing the solar intensity the water temperature at outlet of collector $\left(\mathrm{T}_{\mathrm{w}, \mathrm{oc}}\right)$ increases to the maximum value of $41^{\circ} \mathrm{C}$ at the local time of 12:0013:00 $\mathrm{h}$ that results the maximum temperature difference of water at outlet and inlet of the collector of $16^{\circ} \mathrm{C}$. After that $\mathrm{T}_{\mathrm{w}, \mathrm{oc}}$ decreases with decreasing the solar intensity in the afternoon. Although the temperature variation of water at outlet of heat exchanger $\left(\mathrm{T}_{\mathrm{w}, \mathrm{OHE}}\right)$ along the time exhibits the same trend, the variation seems to be lower. Its temperature exists in the range of $74-83^{\circ} \mathrm{C}$. The variation of flue gas temperature at outlet of heat exchanger $\left(\mathrm{T}_{\mathrm{g}, \mathrm{o}}\right)$ is insignificant and its temperature only exists in the range of $123-126^{\circ} \mathrm{C}$. The temperature difference of flue gas at inlet and outlet of heat exchanger is always direct proportional to that of water at outlet and inlet of heat exchanger. The temperature differences of each fluid at inlet and outlet of heat exchanger are relatively low at time of 12:0013:00 $\mathrm{h}$ in which the water temperature at outlet of collector or inlet of heat exchanger is highest.

Figure 7 shows the relationship of various heat transfer rates and local time. The total solar radiation rate $\left(\mathrm{Q}_{\mathrm{G}}\right)$ increases along the time to the maximum value at noon after that it decrease which is corresponding to the solar intensity in Fig. 5.

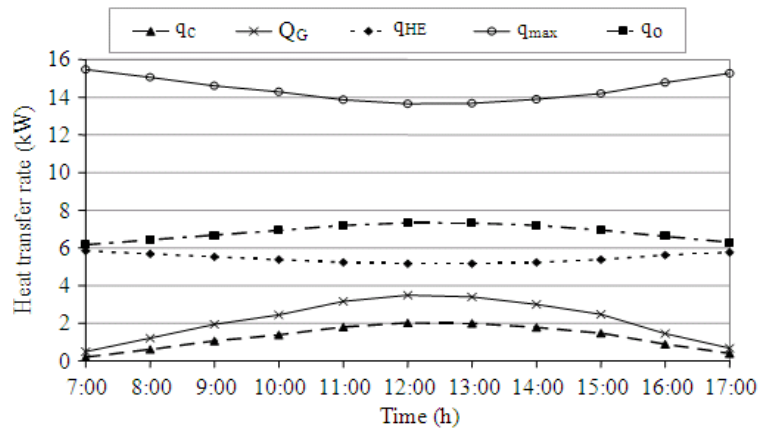

Fig. 7: Relationship of various heat transfer rates and local time

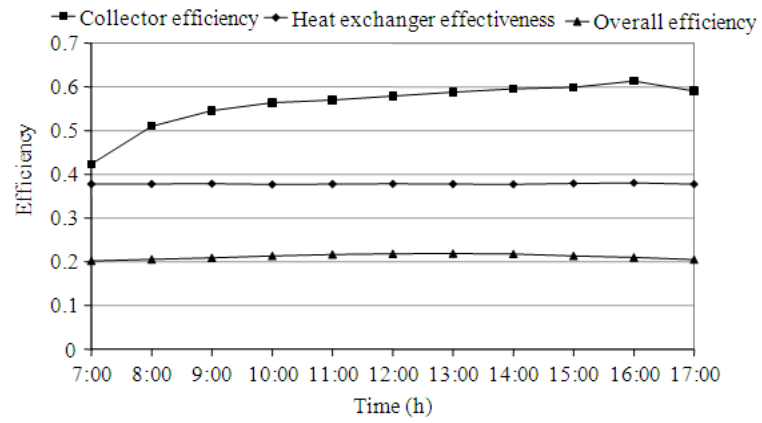

Fig. 8: Variation of efficiency of hybrid system along the local time 
Heat gain of hot water from the solar collector $\left(q_{c}\right)$ is always direct proportional to the total radiation rate. Its maximum value is $2 \mathrm{~kW}$ at noon. Total heat transfer between the flue gas and water $\left(\mathrm{q}_{\mathrm{HE}}\right)$ is always inverse proportional to the total radiation rate but direct proportional to the maximum possible heat transfer rate of heat exchanger $\left(\mathrm{q}_{\max }\right)$. The maximum $\mathrm{q}_{\mathrm{HE}}$ is $6 \mathrm{~kW}$ approximately at 7 and $17 \mathrm{~h}$ and the minimum is $5 \mathrm{~kW}$ at noon. This is because the volumetric flow rates of water and flue gas flowing across heat exchanger are always constant and the flue gas temperature at inlet of heat exchanger is always kept at $150^{\circ} \mathrm{C}$. If the water temperature at inlet of heat exchanger is higher, the maximum possible heat transfer rate of heat exchanger decreases and also the heat gain of hot water from heat exchanger decreases. The decrement of water heat gain from heat exchanger is relative low compared to the increment of that from solar collector. Since the total heat gain of hot water from hybrid system $\left(\mathrm{q}_{\mathrm{o}}\right)$ is the summation of that from solar collect and heat exchanger, it increases along the time to the maximum value of $7 \mathrm{~kW}$ at noon after that it decreases.

Figure 8 shows the variations of collector efficiency, heat exchanger effectiveness and overall efficiency of hybrid system along the local time. The collector efficiency gradually increases from 0.42 and closes to a constant value about 0.6 after 14:00 h. This is because in the morning, the solar intensity and air temperature are very low as seen in Fig. 5 so the total solar radiation rate incident on the collector surface area is low as the heat loss from collector to surrounding is high. These result the low heat gain of water from collector and the low collector efficiency. With an increase in the solar intensity and air temperature from 7:00-13:00 $\mathrm{h}$, the collector efficiency is increased. Thereafter its efficiency is nearly constant. This is because although the solar intensity decreases, the air temperature in the afternoon is higher that in the morning thus the heat loss to surrounding is lower. Moreover there is some thermal energy stored in water in the condenser tank which is available.

The heat exchanger effectiveness is nearly constant at 0.38 along the local time of the day. This is because its effectiveness is independent on its surrounding condition and the inlet flow rate and temperature of flue gas which is a heat source of heat exchanger are constant. The variation of overall efficiency of hybrid system along the time is insignificant and its value is rather low about 0.2 . This is because the auxiliary heat of rice husk combustion that is released from the cyclone furnace is very high over 2 times of the maximum possible heat transfer rate of heat exchanger $\left(q_{\max }\right)$ thus the overall efficiency is low. However this problem may be solved by adjusting the rice husk consumption and the water flow rate which will be done in our future research and then the cost and energy consumption index should be reduced.

\section{CONCLUSION}

It can be summarized from all results as follows:

- The hybrid water heater system with optimum design of both thermal performance and economic can be obtained and produce the hot water at the temperature exceeding $70^{\circ} \mathrm{C}$ and the flow rate of $1 \mathrm{~m}^{3}$ day $^{-1}$

- The thermal performance of this optimum hybrid water heater system was investigated along the time of the day from 7:00 am-5:00 pm in summer and found that the temperature of hot water that was available of this hybrid system existed in the range of $74-83^{\circ} \mathrm{C}$ with the average collector efficiency per day of 0.56 , the heat exchanger effectiveness of 0.38 and the overall efficiency of 0.2

\section{ACKNOWLEDGEMENT}

This research was done at Faculty of Engineering, Naresuan University, Thailand under the auspices of National Research Council of Thailand (under Contact No. EN-AR-065/2552).

\section{REFERENCES}

Assilzadeh, F., S.A. Kalogirou, Y. Ali and K. Sopian, 2005. Simulation and optimization of a LiBr solar Absorption cooling system with evacuated tube collectors. Renew. Energy, 30: 1143-1159. DOI: 10.1016/j.renene.2004.09.017

Balzar, A., P. Stumpf, S. Eckhoff, H. Ackermann and M. Grupp, 1996. A solar cooker using vacuumtube collectors with integrated heat pipes. Solar Energy, 58: 63-68. DOI: 10.1016/0038092X(96)00024-2

Beikircher, T., G. Goldemund and N. Benz, 1996. Gas heat conduction in an evacuated tube solar collector. Solar Energy, 58: 213-217. DOI: $10.1016 / \mathrm{S} 0038-092 \mathrm{X}(96) 00065-5$

Esen, M., 2004. Thermal performance of a solar cooker integrated vacuum-tube collector with heat pipes containing different refrigerants. Solar Energy, 76: 751-757. DOI: 10.1016/j.solener.2003.12.009.

Kim, Y. and T. Seo, 2007. Thermal performances comparisons of the glass evacuated tube solar collectors with shapes of absorber tube. Renew. Energy, 32: 772-795. DOI: $10.1016 /$ j.renene.2006.03.016 
Li, M. and L.L. Wang, 2006. Investigation of evacuated tube heated by solar trough concentrating system. Energy Convers. Manage., 47: 3591-3601. DOI: 10.1016/j.enconman.2006.03.003

Morrison, G.L., I. Budihardjo and M. Behnia, 2004. Water-in-glass evacuated tube solar water heaters. Solar Energy, 76: 135-140. DOI: 10.1016/j.solener.2003.07.024

Sharma, S.D., T. Iwata, H. Kitano and K. Sagara, 2005. Thermal performance of a solar cooker based on an evacuated tube solar collector with a PCM storage unit. Solar Energy, 78: 416-426. DOI: 10.1016/j.solener.2004.08.001
Zhang, X.R. and H. Yamaguchi, 2008. An experimental study on evacuated tube solar collector using supercritical $\mathrm{CO}_{2}$. Applied Therm. Eng., 28: 1225-1233. DOI: 10.1016/j.applthermaleng.2007.07.013 